\title{
Conditions of Facilities and Infrastructure for Inclusive School Education Services
}

\author{
Melda Rumia Rosmery Simorangkir \\ Faculty of Teacher Training and Education, Universitas Kristen Indonesia, Jakarta, Indonesia
}

Email address:

meldasimorangkir82@gmail.com

\section{To cite this article:}

Melda Rumia Rosmery Simorangkir. Conditions of Facilities and Infrastructure for Inclusive School Education Services. International Journal of Elementary Education. Vol. 10, No. 2, 2021, pp. 38-41. doi: 10.11648/j.ijeedu.20211002.12

Received: May 1, 2021; Accepted: May 18, 2021; Published: May 26, 2021

\begin{abstract}
Educational services for children with special needs are educational services that require special services. This is due to various factors that cause obstacles to students, both cognitive, affective and psychomotor barriers that are caused by developmental disorders in children, either inborn which are permanent or occur during temporary life development. In the Government Regulation of the Republic of Indonesia No. 17/2010 Article 129 paragraph 3 states that students with disabilities include, among others: blind, deaf, speech impaired, mentally retarded, mentally disabled, disabled, learning difficulties, slow learning, autism, motor disorders, including drug victims. banned, and additives, as well as those with disorders that have not yet come. Not much different from Ministerial Regulation No. 70 of 2009 article 3 paragraph 2 states that blind, deaf, speech impaired, mentally retarded, mentally disabled, disabled, learning difficulties, slow learning, autism, motor disorders, including victims of illegal drugs, and additives, those who have a disability, as well as a marker. This study aims to see how educational services in Bekasi, Indonesia provide various facilities and infrastructure in order to service the educational needs of children with special needs and disabilities. This research was also carried out to re-examine the educational background of the teaching staff in these inclusive schools and see how the readiness of the teaching staff to face various updates regarding various information with special needs and disabilities. This study uses a qualitative method with a descriptive approach, from the results of this study it was found that not all inclusive schools have the facilities and infrastructure in accordance with government regulations, besides that the background of the teaching staff in inclusive schools from the four schools only found one person with an educational background specifically, this is of course one of the limitations of the prepared schools and educational infrastructure for children with special needs.
\end{abstract}

Keywords: Facilities, Infrastructure, Inclusion

\section{Introduction}

Children with special needs (ABK) are children who have physical, mental, intellectual, social and emotional limitations that require special education and attention services compared to other children. There are various reactions that parents can do when they have children who are expected to experience specialties when they are born into the world. Oki [4] (p. 886) children with special needs are children who have special disabilities, have different characteristics from other children in general. Children with these special characteristics make them need special education services that are tailored to their talents, potentials and abilities even though they have physical, mental, social emotional barriers and have limitations as well as abilities and intelligence. Mega [6] (p. 2) education services for children with special needs require special attention according to the needs of each child. Both the methods, materials, competency standards to be achieved and the media used are specially designed for them. The same opinion is expressed by Nadiyah [1] (p. 11) that children with special needs are children who have physical, mental and characteristic deviations that make these children need educational services, guidance and various trainings to be able to deal with their limitations. Deviations both physically, mentally, emotionally, and in excess intelligence in children will certainly be accompanied by behavioral disturbances in children. 


\section{Theoretical Basis}

\subsection{Inclusive Education Services}

In accordance with Law of the Republic of Indonesia [14] No. 20 of 2003 concerning the National Education System in article 1 paragraph 1 explains that education is a conscious and planned effort to create an atmosphere of learning and the learning process so that students actively develop their potential to have religious spiritual strength, self-control, personality, intelligence, morals noble, as well as the skills needed by himself, the community, the nation and the state. In this case, the law that receives education is not only regular children around us, but also children with special needs and disabilities. Nissa [11] (p.54) In education services for children with special needs and disabilities, the government provides various forms of education services such as special schools, inclusive schools, special needs schools, home schooling, therapy homes, and various other forms of education, both formal and informal. Simo [15] (p.91) in the context of education for children with special needs will refer to the ability in various existing activities which are parts that need to be done, such as reading and writing exercises that need to be done repeatedly to be able to develop their abilities. To be able to help develop reading and writing, children with special needs can attend educational services in special schools. The 1993 National Education System, which became a breakthrough in special education in Indonesia, explains that the Special School is an educational institution that aims to help students with physical and / or mental, behavioral and social disabilities to be able to develop attitudes, knowledge and skills as individuals and members of society in establish reciprocal relationships with the surrounding social, cultural and natural environment and can develop skills in the world of work or attend further education. Partina [16] (p.1) explains that special education is education that is specifically implemented for students who experience physical and mental obstacles.

Meanwhile, the inclusive school Angga [9] (p.1) revealed that it is an educational service provided to students who have physical and mental limitations, potential intelligence and special talents, autism, mental retardation, homeless people and other talents and potentials. Inclusive education does not seem much different from special schools, the difference appears when regular children together with children with special needs are in the same school following learning in the same class as regular children. Febri [16] (p.83) inclusive education is a learning activity carried out simultaneously between regular students and students with special needs. This school is strongly supported by the government so that it is obliged to provide educators with special education qualifications so that they can realize national education and are supported by psychologists to be able to help students with special needs achieve their learning goals.

\subsection{Inclusive School Teachers}

Special teachers are needed to be able to educate children with needs and disabilities, teachers are an important component for the implementation of teaching and learning activities in schools. Law of the Republic Indonesia [13] No. 14 of 2005 Article 2 paragraph 1 about teachers and lecturers explains that "teachers have a position as professional staff at the levels of primary education, secondary education, and early childhood education in the formal education pathway which is appointed in accordance with statutory regulations." Given the importance of teaching staff in the education unit, this also applies to special and inclusive school education services. Schools with special needs and inclusion have special requirements to accept teaching staff, this is of course also in accordance with Law No. 14 of 2005 article 8 explains that "teachers are required to have academic qualifications, competencies, teacher certificates, be physically and mentally healthy, and have the ability to realize the goals of national education." for that it is clear that teachers are those who have a teacher education of at least a diploma 4 or equivalent to a bachelor's degree. In the article it is also explained that they must have an educator certificate, this certificate can be given to teachers who always equip themselves with various trainings to get educator certification from the government and are equipped with physical and mental health so that they can be role models for students. Indah and Binahayati [3] (p.223) explain that the inclusive education unit is a form of equity and embodiment in the world of education without having to distinguish between children with special needs and other children in general, in inclusive education all children with special needs can receive the same education in the general class used to be with regular children his age. Through inclusive education, children with special needs and disabilities are not discriminated against the conditions they experience.

Teachers who handle students with special needs have special criteria, Nur [2] (p.1) explains that the transition phase is a period that is quite difficult to pass for children with special needs and disabilities. In this phase the child experiences a transition in the context of education from home to school, teachers have a very important role in that phase to design service programs together with parents. Based on these needs, of course, educators who are expert and professional in special education are needed so that they do not experience difficulties when faced with this situation. Conny [12] (p.7), through the results of his research, explains that an educator needs to make adequate preparation, have effective communication, have skills in collaborating with parents and of course this requires an educational background and experience of educators in accordance with their field. This is certainly one of the strong bases for educators with special needs and disabilities who require different educational backgrounds and special skills. Bayu [7] (p.4) Inclusive schools are schools that carry out education for children in general with the government curriculum, but in the classroom the children at these schools learn together with children with special needs, the curriculum and programs are tailored to the needs of children with special needs in each student. 


\subsection{Inclusive School Support Tools}

In addition to teaching staff, infrastructure is also a part that needs to be considered for inclusive schools, it cannot be denied that not all inclusive schools fulfill the facilities and infrastructure according to the needs of children with special needs. Reno [5] (p. 119) reveals that in the city of Padang, Indonesia, the maintenance of inclusive education is carried out in a balanced manner according to the environment and resources it has. In this case, the people of Padang city really maintain the state of the facilities and infrastructure for inclusive education to maintain the quality of education in these schools. Reni and Vitri [8] (p. 41) stated that the facilities and infrastructure for inclusive education, both software and hardware, are quite important to optimize teaching and learning activities and are a means of supporting the mobilization of children with special needs in these schools. The maximum possible educational facilities and infrastructures must be provided when referring from this perspective so that learning activities of children with special needs can be carried out properly. The availability of educational facilities and infrastructure for children with special needs is sometimes hampered by costs, and the inability of educators to prepare for the needs of students with special needs, this is expressed Winda [10] (p. 195). This research was conducted to measure the availability of facilities and infrastructure in inclusive schools to support learning activities for children with special needs in these schools.

\section{Research Methods}

The research was conducted with a qualitative method with a descriptive approach, in this study, the data collection method used was primary data sources and secondary data sources. Primary data sources include observation, interviews, documentation, and triangulation. The informants of this study were teachers and educators and education staff in four schools. Meanwhile, secondary sources are indirect sources that provide data to data collectors, such as interviews with teachers or in the form of documents

\section{Discussion and Results}

This research was conducted in four government-owned inclusive elementary schools in East Bekasi - Indonesia. Basically, not all educators recognize the characteristics of the special needs of students in the school where they teach. One FA respondent who is a teaching staff at the Kalibaru 4 Bekasi Indonesia public elementary school explained that he had been teaching at this school for a long time. For a long time, our school has accepted students with special needs and disabilities, respondents are not really able to distinguish the characteristics of students with special needs. Respondents only predict the child's needs, because they have never attended training on students with special needs so they don't really understand. Many teachers who also experienced the same thing as FA respondents sometimes asked other people with a variety of information to enrich their understanding. Education for children with special needs is now entering the era of education 4.0 not all of the educators in the research location understand it, most of them think that it is only in the industrial sector and far from education. Many of them also did not think that the education era 4.0 should also be prepared for students with special needs and disabilities. As to what will be prepared for them and how to face this education era, I as a teacher, it feels like I need to be enriched again and try to learn again so as not to miss the developing information.

Basically, the educational facilities and infrastructure for children with special needs in Indonesia have been regulated in Government Regulation No. 43 of the year. 1998 concerning efforts to improve the social welfare of persons with disabilities.

Article 5: "Every person with disabilities has the opportunity in all aspects of life and livelihood."

In this article, it is explained that there is no difference in opportunities for both disabled and non-disabled individuals. Then in article 10 to article 22, it is explained about accessibility for people with disabilities, both physical and non-physical accessibility as a whole contained in that article. The reality is that people with disabilities to access health services are still not friendly, this can be seen from the health service facilities, which are places used to carry out promotional, preventive, curative and rehabilitative health service efforts carried out by the government, this is in the Health Law article 139 (2)). it is said that; The government is obliged to guarantee the availability of health service facilities and facilitate persons with disabilities to be able to live independently and productively socially and economically. So that the government needs to pay attention and consider policies for Persons with Disabilities. Even though in reality in the field, educational facilities and infrastructure are still far from sufficient to meet education services for children with special needs.

The principal of the Jatimekar I state elementary school explained that this school has 37 educators, 6 of which are civil servants and the rest are honorary educators, the principal also explained that there is no special preparation to face the 4.0 education era, especially for students with special needs and disabilities, however they are ready to learn about new things that are developing. This is also good news, various trainings are also needed for educators to complement their abilities in dealing with children with special needs. Facilities and infrastructure both soft and hard equipment in education are needed, there is no difference in the rights of children with special needs with other children. They are both the nation's children and have the right to receive a proper education. Educational services must support the fulfillment of facilities and infrastructure so that learning activities take place well. Various trainings are also needed for educators to experience updates on various developmental conditions regarding children with special needs and disabilities. It is hoped that the need for educators and educators can be realized soon, teachers are also expected to continue to seek information and improve themselves for the maximum development of students. 


\section{Acknowledgements}

The researcher would like to thank God Almighty for his grace for this research to be completed. To the Universitas Kristen Indonesia for supporting the implementation of this research, To the Universitas Kristen Indonesia research institute which has guided and reviewed every article, to the Research and Technology and Higher Education which has given me the opportunity to receive research grants for beginner lecturers so that this research can be carried out, to the four school principals, educators and personnel

\section{References}

[1] Abdullah, N. (2013). Mengenal anak berkebutuhan khusus. Magistra, 25 (86), 1.

[2] Azizah, N. (2016). Kompetensi guru pendidikan khusus dalam pendidikan transisi. JPK (Jurnal Pendidikan Khusus), 12 (1), $1-13$.

[3] Darma, I. P., \& Rusyidi, B. (2015). Pelaksanaan sekolah inklusi di Indonesia. Prosiding Penelitian dan Pengabdian kepada Masyarakat, 2 (2).

[4] Dermawan, O. (2013). Strategi pembelajaran bagi anak berkebutuhan khusus di slb. Psympathic: Jurnal Ilmiah Psikologi, 6 (2), 886-897.

[5] Fernandes, R. (2018). Adaptasi Sekolah Terhadap Kebijakan Pendidikan Inklusif. Jurnal Socius: Journal of Sociology Research and Education, 4 (2), 119-125.

[6] Iswari, M. (2007). Pendidikan Kecakapan Hidup Bagi Anak Berkebutuhan Khusus.
[7] Pamungkas, B. (2016). Urgensi Pendidikan Karakter untuk Mengoptimalkan Layanan Pendidikan Bagi Siswa Berkebutuhan Khusus di Sekolah Inklusif.

[8] Rezeki, N. F., \& Rusyidi, B. (2016). Pekerja Sosial Dan Pendidikan Inklusi. Prosiding KS, 2 (2).

[9] Saputra, A. (2016). Kebijakan Pemerintah Terhadap Pendidikan Inklusif. Golden Age: Jurnal Ilmiah Tumbuh Kembang Anak Usia Dini, 1 (3), 1-15.

[10] Sari, W. Q. (2012). Pelaksanaan Inklusi di Sekolah Dasar Negeri 14 Pakan Sinayan Payakumbuh (Deskriptif Kualitatif). Jurnal Penelitian Pendidikan Khusus, 1 (1).

[11] Tarnoto, N. (2016). Permasalahan-permasalahan yang dihadapi sekolah penyelenggara pendidikan inklusi pada tingkat SD. Humanitas: Jurnal Psikologi Indonesia, 13 (1), 50-61.

[12] Titone, C. (2005). The philosophy of inclusion: Roadblocks and remedies for the teacher and the teacher educator. The Journal of Educational Thought (JET)/Revue de la Pensée Educative, 7-32.

[13] Undang-Undang Republik Indonesia No. 14 Tahun 2005 Tentang Guru dan Dosen.

[14] Undang-Undang Republik Indonesia No. 20 tahun tahun 2003 tentang Sistem Pendidikan Nasional.

[15] Vehmas, S. (2010). Special needs: a philosophical analysis. International journal of inclusive education, 14 (1), 87-96.

[16] Yatmiko, F., Banowati, E., \& Suhandini, P. (2015). Implementasi pendidikan karakter anak berkebutuhan khusus. Journal of primary education, 4 (2), 77-84. 